\title{
A Conceptual Approach of Information Technology in Environment Science: Research Area and Prospects of Database Generation
}

\author{
Soumendra Nath Talapatra ${ }^{1, \star}$, Abantika Nandy ${ }^{1}$, Partha $\mathrm{Pal}^{2}$ \\ ${ }^{1}$ Department of Environmental Science, University of Calcutta \\ 51/1 \& 2 Hazra Road, Kolkata - 700019, India \\ *Phone: 91-33-2461-5445 \\ ${ }^{2}$ Department of Zoology, Scottish Church College, \\ 1 \& 3 Urquhart Square, Kolkata - 700006, India \\ *E-mail address: ecologylive@yahoo.co.in
}

\begin{abstract}
The data of individual sector on environmental science is compiled in information technology (IT) through database software known as Environment Information (EI). Environment information is an easy accessible database in individual sector, where people can know both new research scope and impact on environment. The present study deals to inform that EI is an area, in which the knowledge of environmental science and IT is combined through database software. In this paper, individual research area, data format and beneficial aspects on environmental science is tabulated for EI. There are several research areas in which the data viz. ecology and ecosystem, biodiversity and conservation of important species, health hazards by diseases, health care facilities, toxicological aspects, wastes types, source generation and management, alternative energy generation facilities, environment education and awareness etc. It is a conceptual approach to gather knowledge of environment related problems and prospects and can easily make a database for the intellectuals, academicians, scientists, regulatory authorities, policy makers, researchers, students etc. These help to know benefits in research area, regulatory process, decision making and proper environment management. People can easily access compiled database in an individual sector of environment science.
\end{abstract}

Keywords: Information technology; Environment information; Computer database; Environment science; Environmental technology

\section{INTRODUCTION}

The knowledge of environmental science is compiled with information technology (IT) commonly called Environment Information (EI). Environment information is an easy accessible database, people can know both new research scope and impact on environment (Mecklenburg v Kreis Pinneburg, 1998). Recent ages are depending on information and technology, which helps to fast, comfortable, luxurious life to human beings. People are now able to cover the distance of months in hours with the help of airways, shorter the duration with the help of cars and motor vehicles and can make cook food quickly in microwaves. 
According to recent technology, communication can easily be made through mobile phones, computers and other electronic gadgets with new functionalities. Due to globalization, doing business is very fast process through, internet viz. email, webcam video, chat etc. One being living in each part of globe can conduct business in other part of globe. It is well known that the smooth technological benefits enjoyed by human beings recently goes on and on and can never stop so do the impacts on environment caused by these activities (Joshi and Lauer, 1998).

It is interesting to note that all of these important household products can now be easily available from internet shopping. But many compiled data regarding impact and benefit on environment are lacking. Information technology can be beneficial to provide proper and suitable database on environment science. The database can be generated from primary and/or secondary data. These different research area as well as protection of health through hospitalization, proper technological knowhow and/or information on education and research sector, recreation and entertainment, eco-tourism, toxicity aspects, disease aspects, biological diversity and conservation of species especially avenue tree, medicinal herbs, insect repellant plants etc., wastes management especially e-wastes, biomedical wastes, solid and liquid wastes, GIS mapping data to know environment health status, etc.

Kolkata city is a hub for IT companies and these companies are working on database based on software programming. Many researches in environmental science and prospects are available in this metropolitan area. It is an achievable concept to gather knowledge of environment related problems and prospects and easily make a database for the intellectuals, academicians, scientists, regulatory authorities, researchers, students etc.

Many studies on environment information have been carried out by many countries of the globe (Yang et al., 2006; Bukachi and Pakenham-Walsh 2007; Valerio, 2009; OECD, 2010 a; b; Benigini et al., 2013; Haydar, 2013) and in India, Ministry of Environment \& Forests (MoEF), Government of India, has been established several data on environment through ENVIS, which provides formulation, implementation and monitoring of the Environmental Information System (ENVIS) Scheme with a view to making it a single-stop web-enabled comprehensive information system but no one has attempted to propose a conceptual approach in easy knowledge sharing database on environment information through a combined effort of information technology and environment science in Kolkata, India.

The present paper aims to know the future scope of research area and benefit of information technology on environment science for government and private sector in relation to Kolkata, India.

\section{RESREARCH AREA AND BENEFIT OF DATABSE GENERATION}

There are several types of research works have already been established in environment science from various research institutes, universities etc. Still many research areas are untouched in relation to field work and survey work. This paper is an emphasizing effort to know various future planning for environment research area, usage of database through information technology and Benefit of EI is tabulated in Table 1. These few research areas and prospects can be compiled through information technology (IT) as a database generation in individual research area, which will support to know in a single platform as compiled database of individual research field. This individual database helps to intellectuals, academicians, scientists, regulatory authorities, policy makers, researchers, students etc. 
From beneficial point of view, these databases will be ready references for all researchers and/or government authorities those who are planning to work on environment science and would like to make decision on environmental issues.

Table 1. Research scope and benefit of environment information.

\begin{tabular}{|c|c|c|c|}
\hline Sl no. & Research area & Database Format & Benefit of EI \\
\hline 1. & Aquatic ecosystem & $\begin{array}{l}\text { Data on ecosystem types, physico- } \\
\text { chemical properties, source of water, } \\
\text { available species diversity, ecosystem } \\
\text { health }\end{array}$ & $\begin{array}{l}\text { Research, conservation } \\
\text { biological and water resources }\end{array}$ \\
\hline 2. & Landscape ecosystem & $\begin{array}{c}\text { Data on ecosystem types, physico- } \\
\text { chemical properties, number of parks, } \\
\text { gardens etc., available species diversity, } \\
\text { ecosystem health }\end{array}$ & $\begin{array}{c}\text { Research, conservation } \\
\text { biological and soil resources, } \\
\text { revenue generation through } \\
\text { parks and gardens }\end{array}$ \\
\hline 3. & Agroecosystem & $\begin{array}{l}\text { Data on ecosystem types, physico- } \\
\text { chemical properties of soil and } \\
\text { irrigation water, crop and vegetables } \\
\text { variety, ecosystem health }\end{array}$ & $\begin{array}{l}\text { Research, conservation crops } \\
\text { and soil resources, } \\
\text { introduction of polyculture } \\
\text { techniques to improve } \\
\text { economical condition }\end{array}$ \\
\hline 4. & Medicinal plant diversity & $\begin{array}{c}\text { Data on species availability, medicinal } \\
\text { value of phytochemicals, parts contain } \\
\text { phytochemicals and types of disease } \\
\text { prevention }\end{array}$ & $\begin{array}{l}\text { Research, conservation and } \\
\text { health care }\end{array}$ \\
\hline 5. & $\begin{array}{l}\text { Insect repellant plant } \\
\text { diversity }\end{array}$ & $\begin{array}{l}\text { Data on species availability, parts } \\
\text { contain phyto-chemicals and types of } \\
\text { disease borne insect repellant }\end{array}$ & $\begin{array}{l}\text { Research, conservation and } \\
\text { health care, no hazardous } \\
\text { effects }\end{array}$ \\
\hline 6. & $\begin{array}{l}\text { Toxicity by inorganic } \\
\text { chemicals }\end{array}$ & $\begin{array}{c}\text { Data on species specific toxicity on } \\
\text { biota }\end{array}$ & $\begin{array}{c}\text { Research, regulations on } \\
\text { environment }\end{array}$ \\
\hline 7. & $\begin{array}{l}\text { Toxicity by organic } \\
\text { chemicals }\end{array}$ & $\begin{array}{c}\text { Data on species specific toxicity on } \\
\text { biota }\end{array}$ & $\begin{array}{c}\text { Research, regulations on } \\
\text { environment }\end{array}$ \\
\hline 8. & $\begin{array}{c}\text { Disease assessment } \\
\text { (vector borne, cancer, } \\
\text { common seasonal } \\
\text { disease) }\end{array}$ & $\begin{array}{c}\text { Data on species specific diseases, } \\
\text { source of carcinogens, medicines } \\
\text { availability }\end{array}$ & $\begin{array}{l}\text { Healthcare improvement, } \\
\text { epidemiology prevention }\end{array}$ \\
\hline 9. & Disease prevention & $\begin{array}{l}\text { Data on common diseases, chances of } \\
\text { new diseases, source of diseases, } \\
\text { treatment facilities, specialist medical } \\
\text { practitioner }\end{array}$ & $\begin{array}{l}\text { Healthcare improvement, } \\
\text { epidemiology prevention }\end{array}$ \\
\hline SI no. & Research area & Database Format & Benefit of EI \\
\hline 10. & $\begin{array}{c}\text { Different surgery } \\
\text { procedure in healthcare }\end{array}$ & $\begin{array}{c}\text { Data on surgery facilities, specialist } \\
\text { surgeons, hospitals and nursing homes }\end{array}$ & $\begin{array}{l}\text { Healthcare improvement, easy } \\
\text { availability during illness }\end{array}$ \\
\hline 11. & Specialist doctor list & $\begin{array}{c}\text { Data on medical facilities, availability } \\
\text { of specialist doctors, hospitals and } \\
\text { nursing homes }\end{array}$ & $\begin{array}{l}\text { Healthcare improvement, easy } \\
\text { availability during illness }\end{array}$ \\
\hline 12. & $\begin{array}{l}\text { Biomedical waste } \\
\text { management }\end{array}$ & $\begin{array}{c}\text { Data on segregation of biomedical } \\
\text { waste and proper management, cost } \\
\text { effective technology }\end{array}$ & $\begin{array}{l}\text { Waste management } \\
\text { technology improvement, } \\
\text { generation reduction }\end{array}$ \\
\hline
\end{tabular}




\begin{tabular}{|c|c|c|c|}
\hline 13. & e-waste management & $\begin{array}{c}\text { Data on segregation of electrical \& } \\
\text { electronics waste and proper } \\
\text { management, cost effective technology }\end{array}$ & $\begin{array}{c}\text { Waste management } \\
\text { technology improvement, } \\
\text { generation reduction }\end{array}$ \\
\hline 14. & $\begin{array}{l}\text { Alternative energy } \\
\text { utilization }\end{array}$ & $\begin{array}{l}\text { Data on types and methodologies of } \\
\text { using alternative source of energy }\end{array}$ & $\begin{array}{l}\text { Development of economic } \\
\text { condition of society, } \\
\text { Conservation of natural } \\
\text { resources }\end{array}$ \\
\hline 15. & Ecosystem health & $\begin{array}{c}\text { Data on species specific biomonitoring, } \\
\text { ecosystem physico-chemical properties } \\
\text { of ecosystem, contributing agents for } \\
\text { ecosystem health hazards }\end{array}$ & $\begin{array}{l}\text { Research, conservation } \\
\text { biological and natural } \\
\text { resources }\end{array}$ \\
\hline 16. & $\begin{array}{l}\text { Conservation technology } \\
\text { and utilization }\end{array}$ & $\begin{array}{l}\text { Data on In-situ \& ex-situ conservation } \\
\text { techniques, different types of banks for } \\
\text { preservation of species }\end{array}$ & $\begin{array}{l}\text { Research, conservation of } \\
\text { threatened species, } \\
\text { development of economic } \\
\text { condition of society } \\
\end{array}$ \\
\hline 17. & $\begin{array}{l}\text { Different research } \\
\text { institute and type of } \\
\text { research }\end{array}$ & $\begin{array}{c}\text { Data on types of R\&D facilities in } \\
\text { different organizations }\end{array}$ & $\begin{array}{l}\text { Present \& future research } \\
\text { application, } \\
\text { commercialization, } \\
\text { development of economic } \\
\text { condition of society }\end{array}$ \\
\hline 18. & $\begin{array}{l}\text { Environment related e } \\
\text { business and ecofriendly } \\
\text { product }\end{array}$ & $\begin{array}{l}\text { Data on types of e-business, knowhow } \\
\text { of biodegradable products \& techniques } \\
\text { for future products }\end{array}$ & $\begin{array}{l}\text { Present \& future research } \\
\text { application, } \\
\text { commercialization, forest } \\
\text { conservation, development of } \\
\text { economic condition of society }\end{array}$ \\
\hline 19. & $\begin{array}{l}\text { Environmental } \\
\text { documentation }\end{array}$ & $\begin{array}{c}\text { Data on present \& future documents on } \\
\text { environment }\end{array}$ & $\begin{array}{c}\text { Present \& future research } \\
\text { application, } \\
\text { commercialization, } \\
\text { development of economic } \\
\text { condition of society, } \\
\text { awareness generation }\end{array}$ \\
\hline 20. & $\begin{array}{l}\text { GIS institute and } \\
\text { environmental research }\end{array}$ & $\begin{array}{l}\text { Data on types of GIS mapping on } \\
\text { environment facilities in different } \\
\text { organizations }\end{array}$ & $\begin{array}{c}\text { Present \& future research } \\
\text { application, } \\
\text { commercialization, awareness } \\
\text { generation } \\
\end{array}$ \\
\hline 21. & $\begin{array}{l}\text { Environment business in } \\
\text { Kolkata }\end{array}$ & $\begin{array}{c}\text { Data on types of business like } \\
\text { consultancy, laboratories, training, etc. } \\
\text { knowhow of technology on } \\
\text { environment }\end{array}$ & $\begin{array}{c}\text { Present \& future research } \\
\text { application, } \\
\text { commercialization, technology } \\
\text { transfer, employment } \\
\text { generation }\end{array}$ \\
\hline 22. & $\begin{array}{l}\text { Research publication in } \\
\text { environment area }\end{array}$ & $\begin{array}{c}\text { Data on different types of environment } \\
\text { area like environment health hazards } \\
\text { and its management }\end{array}$ & $\begin{array}{c}\text { Present \& future research } \\
\text { application, } \\
\text { commercialization, technology } \\
\text { transfer, employment } \\
\text { generation }\end{array}$ \\
\hline
\end{tabular}

\section{CONCLUSION}

In this paper a conceptual approach is made on the basis of database generation through information technology on environmental science. There are several research areas in which the data viz. ecology and ecosystem, biodiversity and conservation of important species, 
health hazards by diseases, health care facilities, toxicological aspects, wastes types, source generation and management, alternative energy generation facilities, environment education and awareness etc. on environmental science can be compiled as information through information technology. These help to know benefits in research area, regulatory process, decision making and proper environment management. People can easily access compiled database in an individual sector of environment science.

\section{Acknowledgement}

The authors convey their gratitude to the Department of Environmental Science, University of Calcutta, for providing the necessary facilities for doing this paper.

\section{References}

[1] Bukachi F., Pakenham-Walsh, N., Chest 132 (2007) 1624-1630.

[2] Haydar A., Procedia - Social and Behavioral Sciences 93 (2013) 695-698.

[3] Joshi K., Lauer T. W., Information \& Management 34(6) (1998) 349-360.

[4] Mecklenburg v Kreis Pinneburg, ECJ C321/96 (1998) ECR 3809.

[5] Ministry of Environment \& forests (MoEF), Government of India, Environment Information Division. http://envfor.nic.in/division/introduction-9

[6] Benigni R., Battistelli C. L., Bossa C., Tcheremenskaia O., Crettaz P., Mutagenesis (2013) 1-9.

[7] Organisation for Economic Co-operation and Development (OECD). (2010a). OECD Information Technology outlook 2010. Chapters 5, 6 and 7. Paris: OECD.

[8] Organisation for Economic Co-operation and Development (OECD). (2010b). Recommendation of the Council on Information and Communication Technologies and the Environment. www.oecd.org/document/26/0,3746,en_2649_33757_45073498_1_1_1_1,00.html

[9] Valerio L. G., Toxicol. Appl. Pharmacol. 241 (2009) 356-370.

[10] Yang C., Richard A. M., Cross K. P., Curr. Comput. - Aid. Drug Des. 2 (2006) 135-150. 